ISSN 0258-7122 (Print), 2408-8293 (Online)

Bangladesh J. Agril. Res. 44(4): 695-702, December 2019

Short Communication

\title{
FARMER'S KNOWLEDGE, ATTITUDE AND PRACTICES ON SAFETY, QUALITY AND POST HARVEST MANAGEMENT OF BRINJAL AND TOMATO IN SOME SELECTED AREAS OF BANGLADESH
}

\author{
M. KHATUN ${ }^{1}$ AND M. S. RAHMAN ${ }^{2}$
}

Post harvest management is very important for horticultural crops. The safety and quality of horticultural crops specially vegetables largely depends on its post harvest management. Due to improper management farmers have to bear significant post harvest losses. Post harvest losses of fruits and vegetables are estimated at 5-20\% in developed countries and 20-50\% in developing countries (Mashav, 2010). In Bangladesh, post-harvest losses of fruits and vegetables amount to $16.73-43.5 \%$ which accounts for an annual loss of Tk. 34420 million (Hasan et al., 2010; Kaysar et al., 2016). The country like Bangladesh suffer much of the postharvest losses due to a number of factors such as lack of adequate knowledge and information, the unavailability of appropriate practices under funded research and development (Hasan et al. 2010 and Azad et al., 2014). The quality and nutritional value of fresh vegetables are also affected by postharvest handling and storage condition (Sablani et al., 2006). In order to reduce post harvest losses and to arrest higher profit vegetable producers in the tropics and subtropics relies heavily on chemicals such as fertilizers, pesticides and crop preservatives. Pesticide comes with a specific environmental concern due to their toxicity and persistence in the environment (Lamberth et al., 2013). So, it not only advantages for crop yield but it also have a significant negative impacts.

Farmers directly involved in the handling of pesticides and insecticides and are at a high risk of exposure to these through contact with pesticide residues on treated crops, unsafe handling, storage and disposal practices (Koureas et al., 2014; Manyilizu et al., 2017). They are using a large number of insecticides during the entire period of growth of vegetables, even at fruiting stage. Sometimes they also ignored the recommended waiting period between the harvest and last spray. Improve post harvest practices reduce food losses, increase food quality, food safety and also higher profit for the grower and marketers. So, improve post harvest management is a very important component in reducing production loss of vegetables. Knowledge, attitude and practice (KAP) survey is an essential tool to know the existing post harvest management and farmers views on safety and quality of vegetables.

KAP are the components of human behavior which is responsible for any action in dealing everyday life. These three components are somewhat pre-requisite in

\footnotetext{
${ }^{1}$ Assistant Professor, Department of Agricultural Finance, Bangladesh Agricultural University (BAU), Mymensingh-2202, ${ }^{2}$ Scientific Officer, Agricultural Economics Division, Bangladesh Agricultural Research Institute (BARI), Gazipur-1701, Bangladesh.
} 
adopting new knowledge on safe and quality vegetable production. Knowledge is the result of some activity such as generation, storage, dissemination and utilization of something that entails either information or data. It is usually based on learning, thinking, and proper understanding of the problem area (Azad, 2013). Attitude is defined by Ajzen and Fishbein (1980) as a person's degree of evaluative affect toward a target behavior. An individual may have multiple attitudes about an object, accessing different ones at different points in time (Wilson, 1998). Attitudes are relatively stable and once adopted, can provide a long-term effect (Olgyaiova et al., 2005). Through changing attitude of farmers, it is possible to improve their performance in adoption and commercialization of horticultural products (Meena et. al., 2009).

A good number of researches on knowledge, attitude and practice of the farmers on different issues of crop production were carried out (Yuantari et. al., 2015; Azad et. al., 2014; Assis and Ismail, 2011; Muhammad et. al., 2012; Abbassy, 2017; Amponsah, et. al., 2018; Baksh et al. 2015; Adesuyi et. al., 2018; Mohamed et. al., 2018; Meena et. al., 2009) but unfortunately there is lack of information on KAP on safety, quality and post-harvest management of vegetables. Due to limited knowledge and information on these areas the present study was designed to demonstrate the status of tomato and brinjal grower's knowledge, attitude and current practices regarding safety, quality and post harvest management in some selected areas of Bangladesh. The study was conducted with a structured interview schedule in two Upazila from Jamalpur and Rangpur district of Bangladesh. They were selected based on intensive growing of tomato and brinjal. Total number of respondents was 100 taking 50 from each district.

\section{Safety, quality and post-harvest management of tomato and brinjal cultivation}

\section{Farmers' knowledge}

All the respondents under this study were using chemical fertilizers, insecticides, fungicides and pesticides. At the same time some farmers were using herbicides along with the chemical components as all they believe that these are mandatory for higher yield. These findings are similar to Zawiyah et al., 2007 who indicated that insecticides were used by $98 \%$ of the farmers, followed by bactericides (79\%), nematicides (24\%), and herbicides (5\%) and Mohamed et al., 2018 who indicated that pesticides were indispensable for high crop yield (80\%). Farmers were asked about the harmfulness of the chemical components used in brinjal and tomato cultivation. Among them $84.9 \%$ knew that these are very harmful The study also found that $2.7 \%$ of the respondents still have no idea on the harmful effect of chemical components used in brinjal and tomato cultivation.

The knowledge level of brinjal and tomato farmer on safety, quality and post harvest management was shown by the following Table 1. It shows the number of respondents who answered the 18 statements as whether they know (Yes) means that they gave the correct answer or don't know (No) means that they gave 
the false answer as previously done by Baksh et.al., (2015) and Yuantari et.al., (2015). It is evident from the mean frequencies that $74.61 \%$ of the sample farmers have sufficient knowledge on the safety, quality and post-harvest management of brinjal and tomato cultivation whereas the rest (25.39\%) still unaware of this issue. Farmers had highest knowledge in response to "Good management increases vegetables quality (100\%)", "The level of vegetables loss is more prominent for delay harvesting (98\%)", "Morning is the appropriate time for vegetable harvesting (98\%)" and "The level of vegetable loss is more prominent at storage stage (96\%)". Lowest knowledge was with respect to "Idea on proper storage technique (32\%)" and "It is very important to follow pre harvest interval rules (13\%)".

Table 1. Farmers Knowledge on safety, quality and post harvest management of tomato and brinjal cultivation

\begin{tabular}{|c|c|c|c|}
\hline \multirow{2}{*}{$\begin{array}{l}\text { Sl. } \\
\text { No. }\end{array}$} & \multirow[t]{2}{*}{ Statements } & \multicolumn{2}{|c|}{$\begin{array}{l}\text { Extent of knowledge } \\
(\% \text { of respondents })\end{array}$} \\
\hline & & Yes & No \\
\hline 1. & Good management increases quality & 100 & 0 \\
\hline 2. & $\begin{array}{l}\text { The level of loss is more prominent for delay } \\
\text { harvesting }\end{array}$ & 98 & 2 \\
\hline 3. & Morning is the appropriate time for harvesting & 98 & 2 \\
\hline 4. & $\begin{array}{l}\text { The level of loss is more prominent at storage } \\
\text { stage }\end{array}$ & 96 & 4 \\
\hline 5. & Should collect after natural maturity & 95 & 5 \\
\hline 6. & Variety influences the post-harvest loss & 93 & 7 \\
\hline 7. & Should be free from disease & 92 & 8 \\
\hline 8. & $\begin{array}{l}\text { Should be free from harmful insecticide and } \\
\text { pesticide }\end{array}$ & 85 & 15 \\
\hline 9. & $\begin{array}{l}\text { Good processing and packaging increases net } \\
\text { revenue }\end{array}$ & 79 & 21 \\
\hline 10. & $\begin{array}{l}\text { Large volume transport at a time increases post- } \\
\text { harvest loss }\end{array}$ & 76 & 24 \\
\hline 11. & Idea on safety issues for human consumption & 73 & 27 \\
\hline 12. & Knowledge on sorting and grading & 72 & 28 \\
\hline 13. & Idea on optimum maturity & 71 & 29 \\
\hline 14. & Knowledge on pre and post-harvest handling & 59 & 41 \\
\hline 15. & Idea on proper transportation technique & 58 & 42 \\
\hline 16. & Should be washed after harvesting & 53 & 47 \\
\hline 17. & Idea on proper storage technique & 32 & 68 \\
\hline 18. & $\begin{array}{l}\text { It is very important to follow pre harvest interval } \\
\text { rules }\end{array}$ & 13 & 87 \\
\hline & Summary (mean) knowledge & 74.61 & 25.39 \\
\hline
\end{tabular}

Source: Field survey, 2018. 


\section{Farmers Attitude}

In order to measure farmers' attitude Table 2 enumerates ten statements on which farmers showed their opinions on two scales- agree and disagree as done by Yuantari et al. (2015). Majority of the respondents (82.78\%) attitude was positive to the statement whereas $17.22 \%$ have negative attitude towards the statements means that they disagreed with the statement. Farmers agreed mostly with the statement, "Necessary to circulate more awareness building materials at the farmer level (100\%)", "Ensuring the quality of insecticide and pesticide (100\%)", "Should maintain proper management technique (96.8)" and "Use of pheromone trap and light trap (95.7)". Farmer were disagreed mostly with the statements "Use of bio pesticide and bio insecticide (50.7\%)", "Pre harvest interval rules should follow (40.7\%)" and "Clean the collected vegetables with hygienic water (37.5\%)". It indicates that farmers have a strong believe on using chemical component to reduce insects and pests rather depend on bio pesticide and insecticide.

Table 2. Farmer's attitude towards safety, quality and post harvest management of brinjal and tomato cultivation

\begin{tabular}{|c|c|c|c|}
\hline Sl. No. & Statements & Agree $(\%)$ & Disagree $(\%)$ \\
\hline 1. & $\begin{array}{l}\text { Necessary to circulate more awareness } \\
\text { building materials at the farmer level }\end{array}$ & 100 & 0 \\
\hline 2. & $\begin{array}{l}\text { Ensuring the quality of insecticide and } \\
\text { pesticide }\end{array}$ & 100 & 0 \\
\hline 3. & $\begin{array}{l}\text { Should maintain proper management } \\
\text { technique }\end{array}$ & 96.8 & 3.2 \\
\hline 4. & $\begin{array}{l}\text { Use of pheromone trap and light trap to } \\
\text { reduce insecticide and pesticide application }\end{array}$ & 95.7 & 4.3 \\
\hline 5. & Optimum use of chemical fertilizers & 93.2 & 6.8 \\
\hline 6. & $\begin{array}{l}\text { Sources of pesticides and insecticides should } \\
\text { be taken under strong monitoring }\end{array}$ & 92.6 & 7.4 \\
\hline 7. & $\begin{array}{l}\text { Educate farmers on the optimum application } \\
\text { of insecticide and pesticide }\end{array}$ & 78.4 & 21.6 \\
\hline 8. & $\begin{array}{l}\text { Clean the collected vegetables with hygienic } \\
\text { water }\end{array}$ & 62.5 & 37.5 \\
\hline 9. & Pre harvest interval rules should follow & 59.3 & 40.7 \\
\hline \multirow[t]{2}{*}{10.} & Use of bio pesticide and bio insecticide & 49.3 & 50.7 \\
\hline & Summary (mean) attitude & 82.78 & 17.22 \\
\hline
\end{tabular}

Source: Field survey, 2018 


\section{Farmers Practices}

Farmers practices has enumerated through Table 3. It shows seven practice statements of the study and farmers responses (\%) as always, rarely and never as done by Yuantari et al. (2015). Majority (43.93\%) of the respondents stated that they always practice these statements whereas a significant portion of the respondents $(38.40 \%)$ opined that they never follow this statement in the cultivation of brinjal and tomato. Among the respondents $88.7 \%$ told that they timely apply quality pesticide and insecticide. But at the same time, $66.3 \%$ of the respondents always apply unnecessary insecticide and pesticide. This might be due to the knowledge gap of the farmers and their traditional attitude regarding safety and quality issues of brinjal and tomato cultivation.

Table 3. Farmer practices on safety, quality and post harvest management of brinjal and tomato cultivation

\begin{tabular}{|c|c|c|c|c|}
\hline $\begin{array}{l}\text { Sl. } \\
\text { No. }\end{array}$ & Statements & $\begin{array}{l}\text { Always } \\
(\%)\end{array}$ & $\begin{array}{l}\text { Rarely } \\
(\%)\end{array}$ & $\begin{array}{l}\text { Never } \\
(\%)\end{array}$ \\
\hline 1. & $\begin{array}{l}\text { Farmer thinks about the safety and quality } \\
\text { issue }\end{array}$ & 10.8 & 22.6 & 66.6 \\
\hline 2. & $\begin{array}{l}\text { Farmer applies unnecessary insecticide } \\
\text { and pesticide }\end{array}$ & 66.3 & 8.5 & 25.2 \\
\hline 3. & $\begin{array}{l}\text { Farmer applies bio fertilizer and bio } \\
\text { medicine }\end{array}$ & 19.8 & 37.3 & 42.9 \\
\hline 4. & $\begin{array}{l}\text { Farmer uses pheromone trap, light trap } \\
\text { and some other technology to destroy the } \\
\text { harmful insect }\end{array}$ & 53.4 & 28.7 & 17.9 \\
\hline 5. & Farmer follows pre harvest interval rules & 8.7 & 10.6 & 80.7 \\
\hline 6. & $\begin{array}{l}\text { Farmer timely applies quality insecticide } \\
\text { and pesticide }\end{array}$ & 88.7 & 2.3 & 9.0 \\
\hline \multirow[t]{2}{*}{7.} & Farmer depends on natural maturity & 59.8 & 13.7 & 26.5 \\
\hline & Summary (Mean) practices & 43.93 & 17.67 & 38.40 \\
\hline
\end{tabular}

Source: Filed survey, 2018

\section{Attitude and perceptions towards safe and hygienic brinjal and tomato}

\section{Farmer attitude}

Enumerates nine statements on farmers' attitude towards safe and hygienic tomato and brinjal. In each of the statements farmers showed their views as agree and disagree. Majority of the respondents $(75.2 \%)$ showed positive attitude on the statements in Table 7. Farmers agreed mostly on "Quality seed (100\%)", "Variety should be high yielding (96.7)" and "Proper management of the crop 
field (92.3\%)". Farmer showed disagreed on "Collected vegetables should be sun dried (65.4\%)" and "Clean with fresh water (60.1\%)".

\section{Farmer perception}

Farmers' perception towards safe and hygienic brinjal and tomato cultivation has enumerated in Table 4 where they answer in three different scales - always practice, rarely practice and never practice as done by Yuantari et.al. (2015). Most of the respondents were against the statements as maximum $40.93 \%$ never practiced during the cultivation of brinjal and tomato. Again $38.49 \%$ of the respondents had always practiced following by $20.58 \%$ as rarely practice in brinjal and tomato growing.

Table 4. Perception of brinjal and tomato farmers on safe and hygienic brinjal and tomato cultivation

\begin{tabular}{|c|c|c|c|c|}
\hline Sl. No. & Statement & $\begin{array}{l}\text { Always } \\
(\%)\end{array}$ & $\begin{array}{l}\text { Rarely } \\
(\%)\end{array}$ & $\begin{array}{l}\text { Never } \\
(\%)\end{array}$ \\
\hline 1. 7 & Think about this issue & 54.3 & 23.8 & 21.9 \\
\hline 2. & Collect and sell quickly & 86.0 & 14.0 & 0.0 \\
\hline 3. & Cultivate high yielding variety & 57.3 & 21.1 & 21.6 \\
\hline 4. & $\begin{array}{l}\text { Use bio fertilizer, insecticide and } \\
\text { pesticide }\end{array}$ & 12.2 & 21.7 & 66.1 \\
\hline 5. & Follow pre harvest interval rules & 15.9 & 31.4 & 52.7 \\
\hline 6. & $\begin{array}{l}\text { Make proper management of the crop } \\
\text { field }\end{array}$ & 89.4 & 8.6 & 2.0 \\
\hline 7. & Clean with fresh water & 14.5 & 15.7 & 69.8 \\
\hline 8. & Clean with fresh piece of cloth & 21.3 & 15.6 & 63.1 \\
\hline 9. & $\begin{array}{l}\text { Keep the collected tomato and brinjal in } \\
\text { open sunlight }\end{array}$ & 0.0 & 5.00 & 95.00 \\
\hline & $\begin{array}{l}\text { Keep the collected tomato and brinjal in } \\
\text { bare soil }\end{array}$ & 34.0 & 48.9 & 17.1 \\
\hline & Summary (mean) perceptions & 38.49 & 20.58 & 40.93 \\
\hline
\end{tabular}

Source: Field survey, 2018

Tomato and brinjal farmers are practicing a good number of post harvest management. They had good level of knowledge and positive attitude towards safety and quality issues of tomato and brinjal. A significant number of tomato and brinjal growers were habituated with right practices regarding point of harvesting, packaging, transportation, grading, sorting and storing. They were well informed about the harmfulness of applying insecticide and pesticide in brinjal and tomato cultivation. Though they had enough knowledge on safety and 
quality issues of tomato and brinjal but less than half of the farmers were practicing at farm level. So, still there is floor to improve their practices. In order to bridge the gap between knowledge and practice, new and update technology and information to improve their production performances should disseminate at farm level. Beside motivation training should follow up by the research institution and agricultural extension. This will be helpful for the farmer to come out of their normal trend of cultivation and enable them to use their knowledge without hesitation.

\section{References}

Abbassy, M. M. S. 2017. Farmer's knowledge, attitudes and practices, and their exposure to pesticide residues after application on the vegetable and fruit crops. case study: north of delta, Egypt. Journal of Environmental and Analytical Toxicology, 7(5):1-6.

Adesuyi, A. A., V. C. Nnodu, K. L. Njoku and A. Jolaoso. 2015. Nitrate and Phosphate Pollution in Surface Water of Nwaja Creek, Port Harcourt, Niger Delta, Nigeria. International Journal of Geology, Agriculture and Environmental Sciences, 3(5):14-20.

Ajzen, I. and M. Fishbein. 1980. Understanding attitudes and predicting social behavior. Englewood Cliffs, N. J, Prentice Hall.

Amponsah, S. K., A. Addo, K. Dzisi, B. Asante, and D. Afona. 2018. Assessment of rice farmers' knowledge and perception of harvest and postharvest losses in Ghana. Cogent Food \& Agriculture 4, pp. 1-14.

Assis, K. and H. A. Mohd Ismail. 2011. Knowledge, attitude and practices of farmers towards organic farming. Int. J. Eco. Res. 2(3):1-6.

Azad, M. J. 2013. Farmers' knowledge on postharvest practices of vegetables. Master of Science Thesis, Department of Agricultural Extension \& Information System, Shere-Bangla Agricultural University, Dhaka-1207

Azad, M. J., M. S. Ali and M. R. Islam. 2014. Knowledge on postharvest practices of vegetables. Int. J. Expt. Agric. 4(3):7-11.

Baksh, K., W. Ganpat, and L. Narine. 2015. Farmers' knowledge, attitudes and perceptions of occupational health and safety hazards in Trinidad, West Indies and implications for the agriculture sector. Journal of Agricultural Extension and Rural Development. 7(7):221-228

Hasan, M. K., B. L. D. Chowdhury and N. Akter. 2010. Postharvest loss assessment: a study to formulate policy for loss reduction of fruits and vegetables and socioeconomic uplift of the stakeholders, National Food Policy Capacity Strengthening Programme, FAO, Rome, Italy.

Kaysar, M. I., M. S. Mia, M. S. Islam and A. K. M. G. Kausar. 2016. Postharvest loss assessment of brinjal in some selected areas of Bangladesh. International Journal of Business, Management and Social Research, 2(2):118-124.

Koureas, M., A. Tsakalof, M. Tzatzarakis, E. Vakonaki, A. Tsatsakis and C. Hadjichristodoulou. 2014. Biomonitoring of organophosphate exposure of pesticide sprayers and comparison of exposure levels with other population groups in Thessaly (Greece). Occup. Environ. Med 71, pp. 126-133. 
Lamberth, C., S. Jeanmart, T. Luksch, A. Plant. 2013. Current Challenges and Trends in the Discovery of Agrochemicals. Science, 341(6147):742-746.

Manyilizu, W. B., R. H. Mdegela, A. Helleve, E. Skjerve, R. Kazwala, H. Nonga, M. H. B. Muller, E. Lie, and J. Lyche. 2017. Self-Reported Symptoms and Pesticide Use among Farm Workers in Arusha, Northern Tanzania: A Cross Sectional Study. Toxics, 5:24-37.

Mashav. 2010. Postharvest losses of fruits and vegetables. Available at: http//www.mashav.mfa. gov.il/ mfm/web/main/document.asp?document ID=42327 viewed March, 2019.

Meena, M. S., A. Kumar, K. M. Singh and H. R. Meena. 2009. Farmers' attitude towards post-harvest issues of horticultural crops. Indian Res. J. Ext. Edu, 9 (3):15-19.

Mohamed, A. O., A. A. Mater, A. M.A. Hammad, A. E. S.A. A. M. Eldein, E. M. Eltayeb, A. A. Dahab, A. A. Gader, and A. Abdelbagi. 2018. Knowledge, attitudes and practices of farmers towards pesticides use and handling in greenhouse farms, Sudan. International Journal of Research - Granthaalayah, 6(9):520-534. https://doi.org/10.5281/zenodo.1465024.

Muhammad, R.H., G.C. Hionu and F.F. Olayemi. 2012. Assessment of the post harvest knowledge of fruits and vegetable farmers in Garun Mallam L.G.A of Kano, Nigeria. International Journal of Development and Sustainability, 1(2):510-515.

Olgyaiova, K., E. Pongrácz, T. Mikkola, R. Radoslav Skapa and R. L. Keiski. 2005. Attitudes toward waste minimization in Finland and Czech Republic - Barriers and drivers. In: Proceedings of the RESOPT closing seminar 'waste minimization and utilization in Oulu region: Drivers and constraints' Edited By Eva Pongrácz. Oulu University Press, Oulu, pp. 85 -109.

Sablani, S. S., L. U. Opara, and K. Al-Ballushi. 2006. Influence of bruising and storage temperature on vitamin C content of tomato. J. Food Agric. Environ, 4(1): 54-56.

Yuantari M. G. C., C. A. M. Van Gestel, N. M. Van Straalen, B. Widianarko, H. R. Sunoko and M. N. Shobib. 2015. Knowledge, attitude, and practice of Indonesian farmers regarding the use of personal protective equipment against pesticide exposure. Environ Monit Assess, pp. 187: 142.

Zawiyah, S., Y. B. Che Man, H. Nazimah, C. K. Chin, I. Tsukamoto, A. H. Hamanyza, and I. Norhaizan. 2007. Determination of Organochlorine and Pyrethroid Pesticides in Fruit and Vegetables Using Sax/Psa Clean-Up Column. Food Chem., 102, pp. 98-103. 